\title{
RECENT DEMOGRAPHIC TRENDS IN THE NORTHERN BORDERLAND BETWEEN ITALY AND SLOVENIA: STABILIZATION OR FURTHER REDISTRIBUTION OF POPULATION?
}

\author{
Damir Josipovič ${ }^{1}$
}

Received 26 November 2012; Accepted 20 September 2013

\begin{abstract}
The contribution presents findings from the research on a constitution of new ethnic identities in Alps-Adriatic region. The key question dealt here with was to which extent the recent demographical processes impact the peripheral, mountainous, and ethnically specific cross-border region between Slovenia and Italy. In lay and professional discourse there is still omnipresent mentality of extinguishing Slovene minority in Italy. Applying various demographical methods the article resolves the demographical processes and quantifies the extent of the local Slovene speakers. The author argues that the recent demographical processes of heavy depopulation tend to stabilize towards stagnation. Depopulation is stronger in the Slovenian part of the region, though the traditional Slovene-speaking areas in Italy aren't as threatened as the adjacent Friulian areas. New migration trends along with the generally low fertility contribute to changes in traditional dualistic structure and bring refreshment to remote parts of the border region as well.
\end{abstract}

Key-words: Alps-Adriatic, Venetian Slovenia, Slavia Veneta, Friuli Venezia Giulia, Slovenes in Italy, Valcanale, Resia, Upper Soča/Isonzo Valley, demography, border region

Izvleček: Prispevek predstavlja izsledke raziskave o konstituciji novih etničnih identitet v prostoru Alpe-Jadran. Temeljno vprašanje, ki ga prispevek razrešuje, je, na kakšen način aktualni demografski procesi vplivajo na prekomejno periferno gorsko območje, ki je zaznamovano tudi z etničnimi specifikami. V strokovnem in laičnem diskurzu je še vedno močno prisotna miselnost, da slovenska manjšina na italijanski strani meje izumira. Članek preko aplikacije različnih demografskih metod opredeli trenutne demografske procese in tudi kvantitativno oceni stanje slovenske manjšine in prebivalstva $v$ tem območju sploh. Avtor ugotavlja, da recentni demografski procesi ne znižujejo števila prebivalcev tako močno kot v preteklosti. Depopulacija je sicer močnejša na slovenski strani meje, vendar na italijanski strani meje območja tradicionalne slovenske poseljenosti niso bolj ogrožena od sosednjih furlanskih. Novi migracijski trendi ob splošni nizki rodnosti pa prispevajo k spremembi tradicionalnih dualističnih razmerij in prinašajo demografsko osvežitev tudi v bolj odročne predele.

\footnotetext{
${ }^{1}$ Dr Damir Josipovič, PhD. in Demography and Social Geography, Senior Scientific Associate, Institute for Ethnic Studies, Erjavčeva c. 26, Ljubljana, Slovenia, Phone: +386 41213 861; e-mail: damir.josipovic@guest.arnes.si
} 
Ključne besede: Alpe-Jadran, Beneška Slovenija, Furlanija Julijska krajina, Slovenci v Italiji, Kanalska dolina, Rezija, Zgornje Posočje, demografija, obmejno območje

\section{Introduction}

The central area of the Alps-Adriatic region occupies an effervescent border region usually geopolitically referred to as Northern Adriatic. It covers roughly the Slovenian-Italian border area between the Austrian boundary and the Friulian lowlands. This hilly and mountainous area is marked by vibrant history and numerous boundary shifts in the recent period. Physicalgeographically the area consists of two major features: pre-alpine foothills on the south and high Julian Alps. It represents a transition area from the Southern Alpine range to Adriatic basin (National atlas of Slovenia). The most important geomorphologic features range from low hills to deep and narrow river valleys with steep hills and rocky mountain tops.

Settlement pattern consists of dozens of small villages and hundreds of hamlets and lone houses with municipality centres as the only, rather semi-urban, settlements. With the exception of Gemona/Humin (11.000), Cividale/Čedad (9.000) and Tarcento/Čenta (6.000) on the southwest, none of the towns exceeds 5.000 inhabitants (source: Istat, 2001; 2011). For the Slovenian part of the borderland the situation is even less favourable, since the biggest urban centre (Tolmin) peaks at only 3.500 (source: SORS, 2011).

In general, the settlement type is alpine, sub-alpine and partly Mediterranean. It well corresponds to the climate-orographic gradient since it branches into three distinct sub-mezzo regions: Soča/Isonzo Julian Alps in the north, protodinaric subalpine piedmonts in the centre, and low hills in the southernmost part (Melik, 1960, 9). The ridge between Matajur/Montemaggiore and Musi/Muzci mountains represents a physical-geographic transition between the colder alpine orographic system on one hand and warmer submediterranean/dinaric on the other. However, the prevailing carstic landscape prevents this transitional area to appear as a watershed between Soča/Isonzo and Tagliamento/Tilment rivers. Consequently, the settlements unevenly spread across the countryside, occupying either the valley bottoms or the sunny slopes and tops of gentle ridges. While the former are predominant in the north, the latter are more present in the south of the region (see map 1).

Despite the mountainous landscape there are plenty of border crossings which permit people to communicate and commute, though the effect of administrative adhesion to centres outside the border area (Udine/Videm, Gorizia/Gorica, Nova Gorica and alike) prevents the forming of solid socio-economic ties. The pertinent international boundary course itself represents no major geomorphological obstacle. The boundary between Slovenia and Italy unevenly follows the dividing line between the low hills of Brda/Collio and Friulian lowland from Sabotin above Gorizia to the valley of Idrija/ludrio in the west. From there it follows Idrija's river course to the ridge of Kolovrat, from where it swerves to the west across Matajur/Montemaggiore (1643 m). From there it crosses Nadiža/Natisone River and a couple of small tributaries to reach Breški Jalovec $(1615 \mathrm{~m})$. It then crosses another deep river valley (Učja/Uccea) before it reaches Kanin (2585). Only from there on it follows the watershed up to the mountain of Mangart $(2678 \mathrm{~m})$. Before the boundary reaches the triple border point at Peč/Dreiecke $(1509 \mathrm{~m})$ in the Karavanke range, it once again crosses an important valley of Dolina/Valcanale between Tarvisio/Trbiž and Kranjska Gora (see Map 1). 


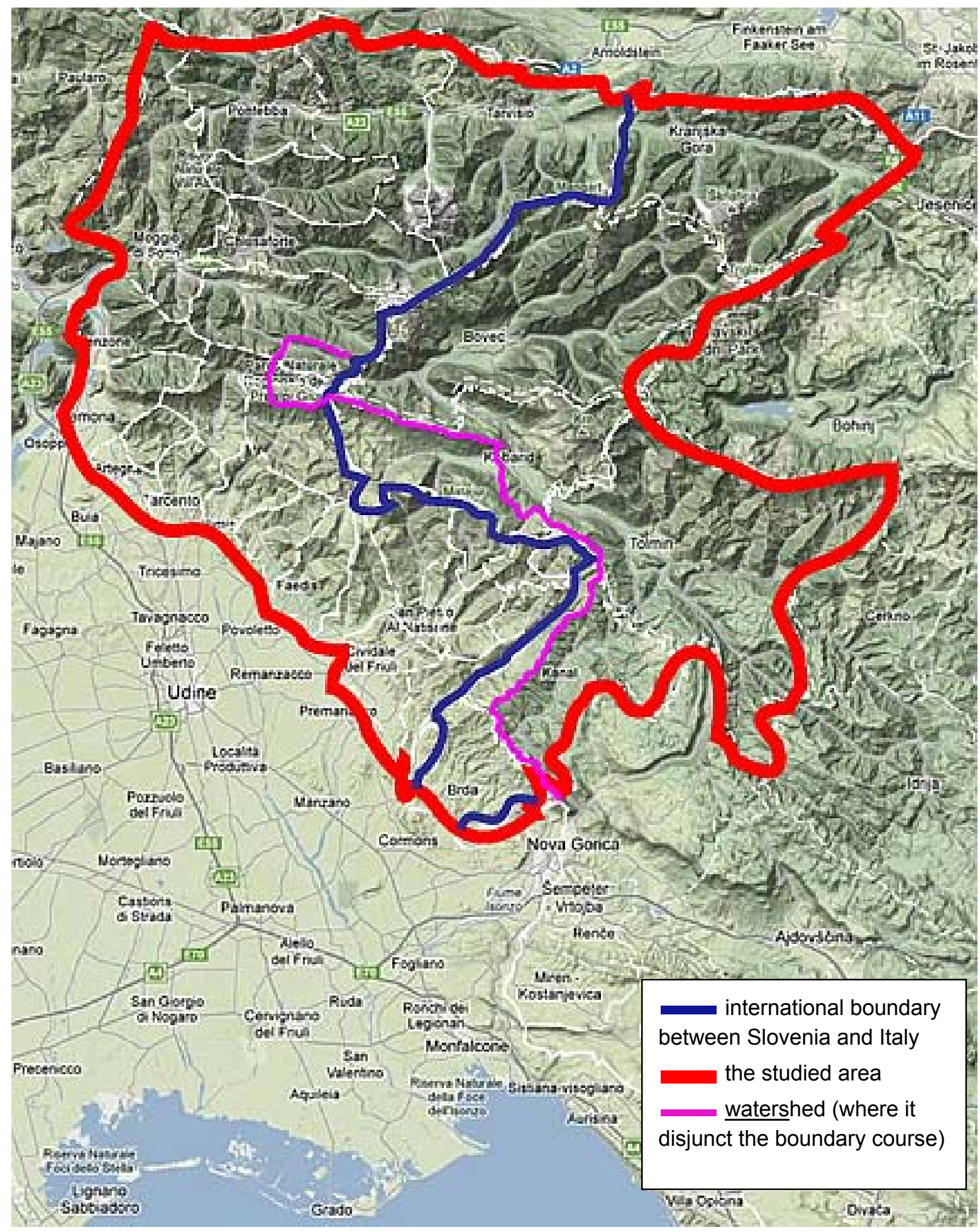

Map 1. Physical geography of northern borderland between Slovenia and Italy (sources: Google Maps, 2012; SORS, 2012).

The Slovenian part of the borderland (i.e. Upper Soča Valley) shares only a few common physical-geographic features with its Italian counterpart. It first transcends into the Dinaric Alps before it reaches the Vipava Valley, while the Venetian Slovenia in Italy represents a piedmont of the Julian Alps. Both parts then rapidly submerge under the alluvium of the Friulian plain, thus forming a Dinaric direction of this contact zone between the mountains and the flatlands. On the contrary, the northern extremity along the Austrian border forms an alpine axis of eastwest direction following the rivers of Sava and Fella/Bela including Valcanale. These diverse landscapes predispose the administrative division in both neighbouring countries. While municipal boundaries in Slovenia follow vague physical features due to the carstic landscape, 
the geomorphology of the Italian part enables wide usage of the watersheds as a clear delimitation between municipalities.

Another important difference between both parts lies in a simple fact that Italian municipalities are more numerous yet much smaller compared to those in Slovenia. The area on the Slovenian side covers $1.417,19 \mathrm{~km}^{2}$, while the Italian $1.617,56 \mathrm{~km}^{2}$, which makes them more or less comparable. Still, the number of municipalities in Slovenia is as low as 6 , and as high as 31 in Italy. This means that an average Slovenian municipality occupies as much as $240 \mathrm{~km}^{2}$, while an average Italian only about $50 \mathrm{~km}^{2}$. In Italy, only the bordering municipality of Tarvisio/Trbiž/Tarvis (209 $\mathrm{km}^{2}$ is somewhat larger, and is similar to the neighbouring municipality of Kranjska Gora in Slovenia (see Map 1, Table 1).

\begin{tabular}{|c|c|c|c|c|c|c|c|c|c|}
\hline Municipality & Province/Region & Area $\left(\mathrm{km}^{2}\right)$ & $\begin{array}{l}\text { Population } \\
2001\end{array}$ & $\begin{array}{l}\text { Statistical } \\
\text { settlements }\end{array}$ & $\begin{array}{l}\text { Inhabited } \\
\text { settlements }\end{array}$ & \begin{tabular}{|l} 
Empty \\
settlements
\end{tabular} & \begin{tabular}{|l|} 
Average \\
size of \\
settlement
\end{tabular} & \begin{tabular}{|l|} 
Population \\
2011
\end{tabular} & \begin{tabular}{|l} 
Indices \\
$2011 / 2001$
\end{tabular} \\
\hline Artegna/Ratenj & Udine/Videm & 11,86 & 2.904 & 3 & 3 & 0 & 960 & 2.879 & 0,99 \\
\hline Attimis/Ahten & Udine/Videm & 33,61 & 1.833 & 12 & 12 & 0 & 155 & 1.865 & 1,02 \\
\hline Chiusaforte/Kluže & Udine/Videm & 101,73 & 815 & 15 & 13 & 2 & 54 & 704 & 0,86 \\
\hline Cividale del Friuli/Čedad & Udine/Videm & 50,94 & 11.373 & 15 & 15 & 0 & 756 & 11.338 & 1,00 \\
\hline Dogna/Dunja & Udine/Videm & 69,38 & 259 & 13 & 9 & 4 & 21 & 192 & 0,74 \\
\hline Drenchia/Dreka & Udine/Videm & 12,78 & 197 & 14 & 13 & 1 & 10 & 134 & 0,68 \\
\hline \begin{tabular}{|l|} 
Faedis/Fojda \\
\end{tabular} & Udine/Videm & 46,67 & 3.070 & 19 & 19 & 0 & 157 & 2.986 & 0,97 \\
\hline Gemona del Friuli/Humin & Udine/Videm & 56,10 & 11.070 & 2 & 1 & 1 & 11.153 & 11.153 & 1,01 \\
\hline Grimacco/Garmak & Udine/Videm & 15,16 & 488 & 14 & 13 & 1 & 29 & 374 & 0,77 \\
\hline Lusevera/Bardo & Udine/Videm & 53,67 & 788 & 8 & 7 & 1 & 101 & 706 & 0,90 \\
\hline Magnano in Riviera/Manjan & Udine/Videm & 8,72 & 2.288 & 2 & 2 & 0 & 1.184 & 2.367 & 1,03 \\
\hline Malborghetto Valbruna/Naborjet - Ovčja vas & Udine/Videm & 124,97 & 1.036 & 7 & 6 & 1 & 162 & 972 & 0,94 \\
\hline Moggio Udinese/Mužac & Udine/Videm & 141,48 & 2.095 & 15 & 14 & 1 & 130 & 1.816 & 0,87 \\
\hline Montenars/Gorjani & Udine/Videm & 20,15 & 536 & 5 & 5 & 0 & 112 & 558 & 1,04 \\
\hline Nimis/Neme & Udine/Videm & 33,18 & 2.825 & 10 & 10 & 0 & 279 & 2.785 & 0,99 \\
\hline Pontebba/Tablja & Udine/Videm & 100,97 & 1.768 & 10 & 8 & 2 & 188 & 1.506 & 0,85 \\
\hline Prepotto/Prapotno & Udine/Videm & 32,59 & 899 & 12 & 12 & 0 & 68 & 811 & 0,90 \\
\hline Pulfero/Podbonesec & Udine/Videm & 49,12 & 1.202 & 26 & 26 & 0 & 40 & 1.035 & 0,86 \\
\hline Resia/Rezija & Udine/Videm & 118,64 & 1.285 & 9 & 7 & 2 & 155 & 1.083 & 0,84 \\
\hline Resiutta/Rezjuta & Udine/Videm & 20,58 & 354 & 2 & 2 & 0 & 158 & 315 & 0,89 \\
\hline San Leonardo/Šent Lenart & Udine/Videm & 26,68 & 1.169 & 16 & 16 & 0 & 73 & 1.164 & 1,00 \\
\hline San Pietro al Natisone/Špeter Slovenov & Udine/Videm & 24,35 & 2.155 & 16 & 16 & 0 & 139 & 2.224 & 1,03 \\
\hline Savogna/Sovodnje & Udine/Videm & 22,48 & 659 & 13 & 13 & 0 & 37 & 483 & 0,73 \\
\hline Stregna/Srednje & Udine/Videm & 20,29 & 456 & 12 & 12 & 0 & 33 & 399 & 0,88 \\
\hline Taipana/Tipana & Udine/Videm & 65,87 & 715 & 7 & 7 & 0 & 97 & 680 & 0,95 \\
\hline Tarcento/Čenta & Udine/Videm & 35,38 & 8.716 & 30 & 30 & 0 & 303 & 9.104 & 1,04 \\
\hline Tarvisio/Trbiž & Udine/Videm & 209,03 & 5.071 & 18 & 12 & 6 & 383 & 4.597 & 0,91 \\
\hline Torreano/Tavorjana & Udine/Videm & 33,67 & 2.266 & 12 & 12 & 0 & 185 & 2.214 & 0,98 \\
\hline Venzone/Pušja vas & Udine/Videm & 54,32 & 2.300 & 9 & 9 & 0 & 248 & 2.230 & 0,97 \\
\hline Dolegna del Collio/Dolenje & Gorizia/Gorica & 12,58 & 435 & 6 & 6 & 0 & 65 & 392 & 0,90 \\
\hline San Floriano del Collio/Števerjan & Gorizia/Gorica & 10,62 & 821 & 7 & 7 & 0 & 114 & 799 & 0,97 \\
\hline Kanal/Canale d'Isonzo & Goriška & 146,53 & 6.320 & 35 & 33 & 2 & 173 & 5.710 & 0,90 \\
\hline Bovec/Plezzo & Goriška & 367,32 & 3.411 & 13 & 13 & 0 & 247 & 3.213 & 0,94 \\
\hline Kobarid/Caporetto & Goriška & 192,73 & 4.592 & 33 & 33 & 0 & 126 & 4.172 & 0,91 \\
\hline Tolmin/Tolmino & Goriška & 382,33 & 12.352 & 72 & 71 & 1 & 164 & 11.626 & 0,94 \\
\hline Brda/Collio & Goriška & 71,97 & 5.823 & 45 & 44 & 1 & 131 & 5.747 & 0,99 \\
\hline Kranjska Gora & Gorenjska & 256,31 & 5.413 & 10 & 10 & 0 & 532 & 5.316 & 0,98 \\
\hline ITALY & 31 & 1617,56 & 71.848 & 359 & 337 & 22 & 207 & 69.865 & 0,97 \\
\hline SLOVENIA & 6 & 1417,19 & 37.911 & 208 & 204 & 4 & 175 & 35.784 & 0,94 \\
\hline BORDER REGION & 37 & 3034,75 & 109.759 & 567 & 541 & 26 & 195 & 105.649 & 0,96 \\
\hline
\end{tabular}

Tab 1. Slovenian-Italian border region, administrative division with some basic statistics (source: ISTAT, 2012; SORS, 2012).

From a closer look the relationship between the size and the relief (geomorphology) becomes more apparent. The Julian Alps are augmenting towards the north so the southerly lying municipalities are generally more populous but smaller due to higher number of valleys and lower ridges. This is also the reason why the Slovenian side has only half a population of the Italian side. This is not generally the situation with the number of settlements. Slovenian part has evidently less settlements, which are bigger in size, though smaller in population. Smaller number of settlements doesn't mean higher intensity in vacating them. Here we deal with the general relationship between the remoteness and depopulation. So is the northern part of the borderland, especially the places of higher altitude, more inclined to losing all of the residents. In the studied area altogether, there are 26 empty settlements with only four of them located in Slovenia. Their spatial distribution is uneven across the border region. For the most part, the Italian empty settlements are concentrated in 8 alpine municipalities in northern half of the region, while all four Slovenian empty settlements are located exclusively 
between the rivers of Soča/Isonzo and Idrija/ludrio in the south. Before we continue with the analysis, we will make a brief historical-geographic account in order to understand the complex regional structure and the changing geopolitical circumstances influencing the demographic structure.

\section{Historical overview}

Prior to the WWII, the region was plentiful of traditional transversal routes and paths accompanied with abundant traffic and contacts (see e. g. Mlekuž, 2002; 2004). While being under the same political organization (Habsburg Empire until 1866), the region of Slavia Veneta (Beneška Slovenija) highly depended on alpine type of farming, which included transhumance and long distance pasturing movements across ridges and mountains (Melik, 1950). With the imposition of the new boundary after 'risorgimento' in 1866, these movements became trans-border until the end of the WWI and the collapse of the Austria-Hungary ${ }^{2}$. The Rapallo Treaty shifted the border to the east for twenty years onto the watershed between the Soča and Sava basins. The latter course of boundary partly corresponds to confines of the studied area (in the Triglav National Park eastward of Bovec). After the WWII the boundary was shifted back to the course of 1918, where it remains until the very presence. The imposition of the boundary in 1866 ultimately precluded the area of Slavia Veneta/Venetian Slovenia from unification under the thence valid ethnic criteria with their linguistic kin.

After the WWII, this northernmost borderland as a part of the Northern Adriatic was far less renowned compared to its southern neighbourhood. The key role was played by the Trieste/Trst crisis and the traumatic boundary making between Italy, The Free Territory of Triest, and Yugoslavia. At that time the general demographic processes were relevant only for the purposes of the pertinent struggle and to the degree of interest of the main stakeholders involved. The latter were, rather expectedly, concentrated more or less to the questions of migration (i.e. exodus, replacement of population, 'humane' resettlement etc.) and ethnic structure (a tracing of the so-called ethnic equilibrium). The plethora of physical-geographic features, which snared populations into linguistic and ethnic kaleidoscope, made this region into a prominent investigative geographical laboratory.

Nevertheless, the recent and contemporary developments of globalizing economy operate in a direction of veiling the local "ethnic" concerns, seemingly to counter the idea of postmodernism and its preoccupation with the self (cf. Harvey, 1989). Accordingly, both neighbouring states here have slowly omitted certain statistical indicators which "measure" ethnic, linguistic, and other "cultural features" of the population. On the other hand we may witness the importance ascribed to the "ethnic" issues by local populations (e.g. treating the rights of national minorities ${ }^{3}$ ). This global-local ambivalence points to the importance of noneconomic factors influencing the local development. Moreover, it implies that we mustn't overlook the power geometry (after Massey, 1993) and its impact on the specific regional and demographic development.

The northern borderland of our primary interest here wasn't of a greater geopolitical focus since the boundary was settled already by the agreement of 1947. After that, the processes on both sides of the Alpine and Sub-Alpine portion of the international boundary evolved more or less independently, partly as a consequence of an imposition of the Iron Curtain. Especially after the WWII, the newly established north-south population mobility towards urban centres in the south replaced the former cross-mountain ties and economy. Due to industrialization, deagrarization, urbanization and other related processes, this peripheral countryside cut by a political boundary consequently suffered a huge population loss which continues into

\footnotetext{
${ }^{2}$ It is important to stress that the boundary was not stable in the period between 1866 and 1920 . Every now and then it shifted for considerable portions, including villages and alpine pastures (the so-called 'planina' [sing.]; 'planine' [plural]). One major shift included wide areas around Breginj and Livek, which were subsequently annexed into Austria-Hungary and, thus, into Slovenia.

${ }^{3}$ The so-called Act on protection of Slovene-speaking minority in Italy (Act no. 38). Further information for example in Brezigar (2004, e.g. 73), Globočnik (2005), and Peršič (2008).
} 
the $21^{\text {st }}$ century. Thus it might be easier to apprehend such tremendous population change in this par excellence border and peripheral region.

\section{Aims and hypothesis}

It has for a long time been maintained that the studied transnational area is very much a depopulation and emigration area from both sides of the international boundary. Both Slovenian and Italian authors, each for their own part, claimed generally the same. The question on Slovene-speaking community in Italian portion of the borderland was a persistent part of such deliberations, though rather in a discriminating manner. The Slovenian authors, for the most part, claimed that the Italian Slovenes are dying out and that too little is being done by the Italian state to prevent that. Here, the hypothesis counters these claims, maintaining that the core of such deliberations lies in the Slovenian view on the question of autochthony. Being a 'leitmotiv' of the Slovenian legislation (i.e. Act on the Slovenes outside Slovenia, the legislation on ethnic minorities in Slovenia), the autochthony principle literally narrowed the Slovene-populated area. Uncritical grasp over the population data on the linguistic adherence back from mid-1800's established a previously non-existent boundary between the Slovene-speaking predominance in the hills and the rest of what is nowadays known as Friuli-Venezia Giulia region. This boundary was almost invariably laid down to separate the mountain foothills and the Friulian basin. Curiously enough, these $19^{\text {th }}$-century-fitted politics were transplanted into the $20^{\text {th }}$, and the $21^{\text {st }}$ century as well. Its main consequence, which preceded the aforementioned writings, was a spatial change of the action-radius of the Slovene minority in Italy, especially for those living in mountainous areas with strong outward migration. Due to the region's remoteness, its peripheral location, and due to specific changes in the global economic development within the capitalist mode of production, it was inevitable to expect that the traditional Slovene-speaking area considered and delimited as autochthonous was going to become largely vacant. Additionally, the relevance and the extent of depopulation across the border region will be questioned as well. According to the theoretical expectation, the population reproduction rates in hilly regions are higher compared to flatlands (Josipovič, $2003 ; 2004$ ). So to experience depopulation in reproductively vibrant area, one have to assume high shares of outward migration. Owing to these assumptions it is presumed that the process of depopulation has depleted.

Hence, the main aim was to assess the recent developments in the field of demography in order to question the very grounding of the repeating claims of depopulation and the lack of internal reproductive resources. Furthermore, the analysis aims at evaluating the demographical impact on the erosion of the settlement pattern (ageing and diminishing population, empty settlements, hamlets, houses, etc.). Since the area was renowned for historical cross-border relations and cross-borderly dependent population owing to specific economy primarily subsisting pasturing (see e.g. Melik, 1950), a special focus aimed at recent cross-border migration as well as the recent changes in settlement structure. The contribution aims at understanding the contemporary demographical developments in the border-region as regards both natural change and migration. It also presents some new findings from the research project ${ }^{4}$, which targeted specifically this border region.

\section{Methodology and sources related issues}

The analyses employed comprise of demo-geographical and cartographic methodology and will provide analyses and thematic maps of a range of studied phenomena. The approach to cartographical representations will chiefly rest on the application of the 'natural break' method to cope with uneven data distributions. Thus the ranges are better represented by their mean value, and the cases within a given range are concentrating more around the range's average. Thus we escape from one-sided portraying as a consequence of systematic errors on the choroplethic maps (see Jenks and Caspall, 1971).

\footnotetext{
${ }^{4}$ The paper is in a great part a result of the research project "Constitution of new national and ethnic identities in Alps-Adria region with a special regard to border areas and the city of Triest, and the 'community-making' aspects of contemporary media« led by Dr Jurić-Pahor (duration: 1.2.2008 - 30.1.2011).
} 
The methods employed will be more thoroughly presented and discussed subsequently within each step of the analyses. Here, they are going to be only briefly mentioned. The indicators used to represent the overall population change are derived from various indices (e.g. index of population change). To understand the changes in the settlement pattern, we applied simple structures (the average population within the settlements, and the population density). To analyse the local population's reproductive capability, we avoided the direct application of various fertility rates. Instead, we applied the approximate reproductive potential (ARP), which is close to and comparable with the total fertility rate, but far more robust in its application (Josipovič, 2006). All the indicators mentioned are robust while enough versatile to achieve high rate of explication, and are not dependent on huge and rather scarcely available datasets for smaller territorial units.

As concerns the estimations, we used the estimation to assess the numbers and shares of Slovene-speaking population, for which there is no existing official data. In so doing we used a combination of various existing assessments in order to adjust them to put up with the recent demographic trends. The analytical findings were compared across the border and considered as a whole before they were eventually synthesised in order to evaluate the research questions and the initial hypotheses.

The geographical scope of the analyses was represented by settlements and municipalities in the area roughly confined with the rivers of Fella/Bela and Tagliamento/Tilment on the west, with the Austrian boundary on the north, with the Friulian lowland and the valley of Vipava to the south, and with the eastern watershed of the Soča/Isonzo Valley. Such delimitation allows an analysis that applies municipal administrative division on both sides of the boundary (31 in Italy, 6 in Slovenia). The Slovenian statistics allow analysing the data at the level of settlements, but are differently organized compared to the Italian. Despite the differences in size and population, municipalities as territorial units allow a relatively broader array of analyses compared to the level of statistical settlements.

The main data providers were the national statistical bureaus. Since the emphasis is on the recent developments, the analyses concentrate mostly on the period after 2000 . This means that practically two series of censuses are considered: those around 2001 and those around 2011. To contrast Italy, Slovenia had practiced a so-called "register census". The latter enables us to access the census data earlier, though it is far from being precise and thorough. We additionally use material from other sources, such as, for example, migration statistics, which are collected on a yearly basis for larger administrative units (provinces, region), and other demographical data on residents, foreign population, etc.

Generally speaking, the Italian statistical office systematically avoids the collecting of "ethnic" statistics. On the eve of fascism in 1921, the more or less last relevant census was conducted to collect the data based on the mother-tongue. Later on, there were only some periodical approximations of ethnic structure, though always as part of strictly dualistic questionnaires excluding other languages (i.e. the binary between the Italian and Slovene speakers). Slovenian case is different. Not until the last "register census" of 2011 did Slovenia abolished the "ethnic" census questions. In the period after WWII (1948-2002) Slovenia systematically included the variety of "ethnic" questions ranging from ethnic/national affiliation, mother-tongue, colloquial language in public, and within a family (Josipovič, 2013), thus making the ethnic statistics one of the hallmarks of everyday life. Nevertheless, the growing questionability of the ethnic data gathered by the last census of 2002, its deepening politicization, and failing interpretations ${ }^{5}$, along with the recent austerity measures, created the grounds of avoiding

\footnotetext{
${ }^{5}$ High shares of non-response (the categories "did not want to reply" and "unknown" ethnic affiliation) rendered the 2002 census very difficult to analyse. Consequently, the lower shares of Slovenes have misled many scholars into the straightforward and false claims. Only a handful of scholars considered the lowering number of Slovenes through the lens of much higher non-response than ever before. Namely, the thorough analysis revealed that the non-response should not be included in an overall statistical breakdown. Additionally, the question on mother tongue combined with the question on ethnic affiliation in comparison with the statements given at the former census of 1991, showed even higher share of population considered as Slovenes (Josipovič 2007). On the contrary, the census data from 2002 show diminishing shares of other ethnicities (especially those of former Yugoslavia), which indicates an accelerated assimilation (ibid.).
} 
a classical door-to-door survey census method. Since the ethnic issues along the borders are of paramount importance for policy makers, the local populations involved, and other partakers, the question on the ethnic structure is analytically addressed as well.

\section{Recent demographic developments in the northern borderland between Italy and Slovenia}

From a broader European perspective the last few decades have purportedly witnessed completely new dynamics of demographic development. As far as "linear" ethnic delimitations were concerned, the former predominantly dualistic relationships were being thereafter "overlaid" or "penetrated" with high numbers of immigrants from far-flung countries. Spatial relations tended to become more and more complicated and blurred. And the national statistical bureaus have gradually become incapable of capturing the heavily accelerated population dynamics. Here, in Thomas H. Eriksen's words, the 'overheated' boundaries play a pivotal role. Theoretically, these series of events may be portrayed as the third demographic transition (Coleman, 2006). Apart from their demographical consequences, the cross-border population processes stem from rising distances required for globalizing capital flows and changed mode of spatial production, which lie at the very core of the change. Though the third demographic transition paradigm somehow favours "the old regimes" of spatial relations, one cannot deny its underlying need to refocus from a simplified linear dualism to multilateral complexity of spatial relations. We will approach to our analysis using this optic, however, bearing in mind that the spatial demographic relations in a given region are far from being simple.

\subsection{Italian part}

Friuli - Venezia Giulia is one of the five Italian autonomous regions. It is located in the northeasternmost part of Italy and it borders Slovenia (Goriška and Obalno-kraška regions) and Austria (Carinthia). It occupies an area of $7,855 \mathrm{~km}^{2}$ with $1,220,078$ inhabitants (census 2011, Istat). With a population density of 155 inhabitants per $\mathrm{km}^{2}$, Friuli Venezia Giulia is the most densely populated region in the central part of Alps-Adriatic area. Administratively, it consists of four provinces: Udine, Pordenone, Trieste, and Gorizia. The studied border region almost entirely belongs to the Province of Udine, except the municipalities of Dolegna/Dolenje and San Floriano/Števerjan, which belong to the northernmost edge of the Province of Gorizia. Creating a rim with its northern extremity around the Slovenian municipality of Brda/Collio, the Gorizia Province stretches between the Pre-alpine hills all the way to the Adriatic Sea.

Being the prominent feature of the autonomous border region, we must consider the question of the Italian Slovenes as well. The traditional Slovene-speaking areas in Friuli Venezia Giulia consist of Valcanale around Tarvisio/Trbiž/Tarvis (formerly part of Austrian Carinthia), Slavia Veneta around Cividale/Čedad, the area around Gorizia/Gorica, and the province of Triest/Trst. Slavia Veneta (Venetian Slovenia or Beneška Slovenija) is considered as one of the major traditional areas of Slovene-speaking population of today's Italy (see Map 2). The last official census there was that of 1921 when some $70 \%$ or 36,000 out of 52,000 residents in 15 municipalities were considered Slovene-speakers, and the rest represented Friulians (e.g. Roglić, 1946). These numbers were disputed by Feigel who, citing the Italian sources, estimated the number of Slovene-speakers between 50,000 and 60,000 (e.g. Feigel and Nanut, $1950,17)$. In Valcanale, the Slovene-speaking population was estimated at about 3,000 persons before WWII (Roglić, 1946). Together with provinces of Gorizia $(28,000)$ and Triest (62,000), the number of Slovenes ranged between 130,000 and 150,000 persons before WWII (ibid.; Stranj, 1999). Nevertheless, the last Austrian census in 1910 and its revision in 1911 showed that the number of Slovenes in Triest province was underestimated, and the corrected number peaked to 80.000 'Yugoslavs' (Roglić, 1946). This number was later on supported with the results of 1911 elections, where the number of Slovenes was set at 83,000 accordingly (Stranj, 1999, 299). After the exodus (roughly about 40.000 Slovenes) under the fascism (ibid.), the post-war number of Slovenes in Friuli Venezia Giulia was estimated to range between 85.000 and 110,000 persons (Stranj, 1983). The lower estimation was confirmed, for instance, by Bufon (1992). 


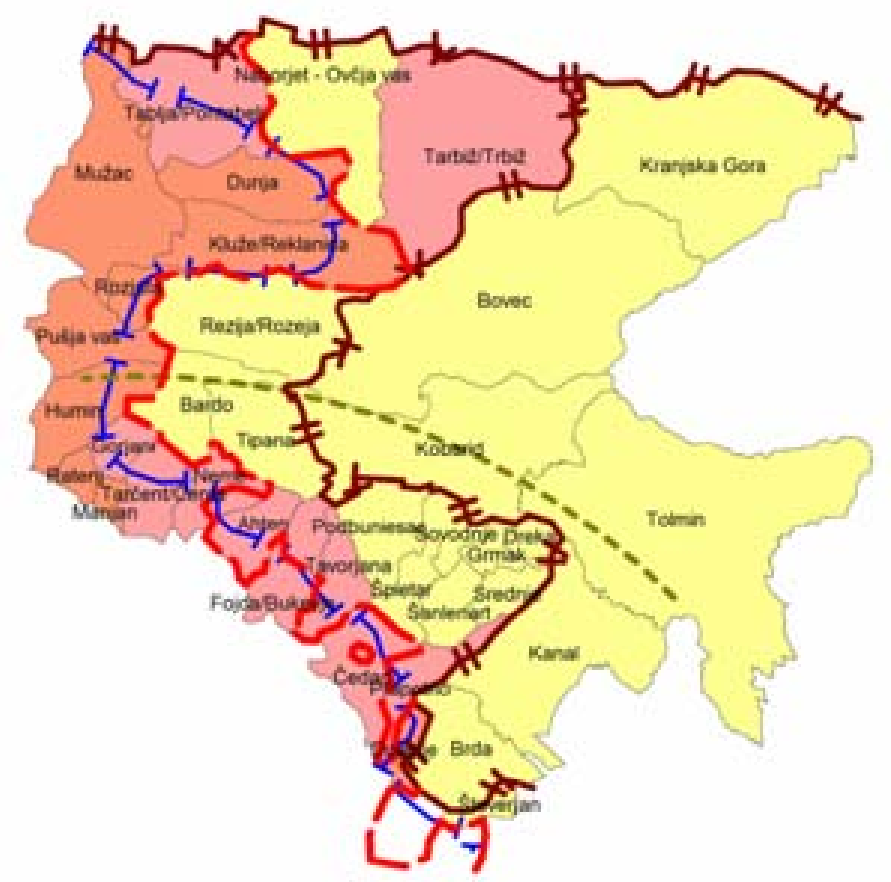

Sovane-speaking arta

Alpire and Previene bonsteriend

Shovenespesing menerty (10)

Sloveresoswing mach (10)

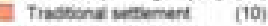

H- intermetional boundary

- sub-medecranean reach

- area under special srotection

F Sovenespeviving area

Author: D. Sonicowt c2013

Map 2. Municipalities under special protection in the Alpine and pre-Alpine borderland between Slovenia and Italy (sources: Rutar, 1899: 54-56; Kos, 1933: 38-39; Feigel, 1950: 11-12; Stranj, 1999: 26; Presidential Decree upon the Act $n^{\circ} 38$ (2001; 2007).

Apart from the census data, there have been some official inquiries carried out, mostly in connection with a pertinent census. In spite of their official status, the only aim was to assess the aforementioned ratio between the Italian-speakers on one hand, and the Slovene-speakers on the other. These approaches utterly neglected the existence of other languages, in the first place the Friulian.
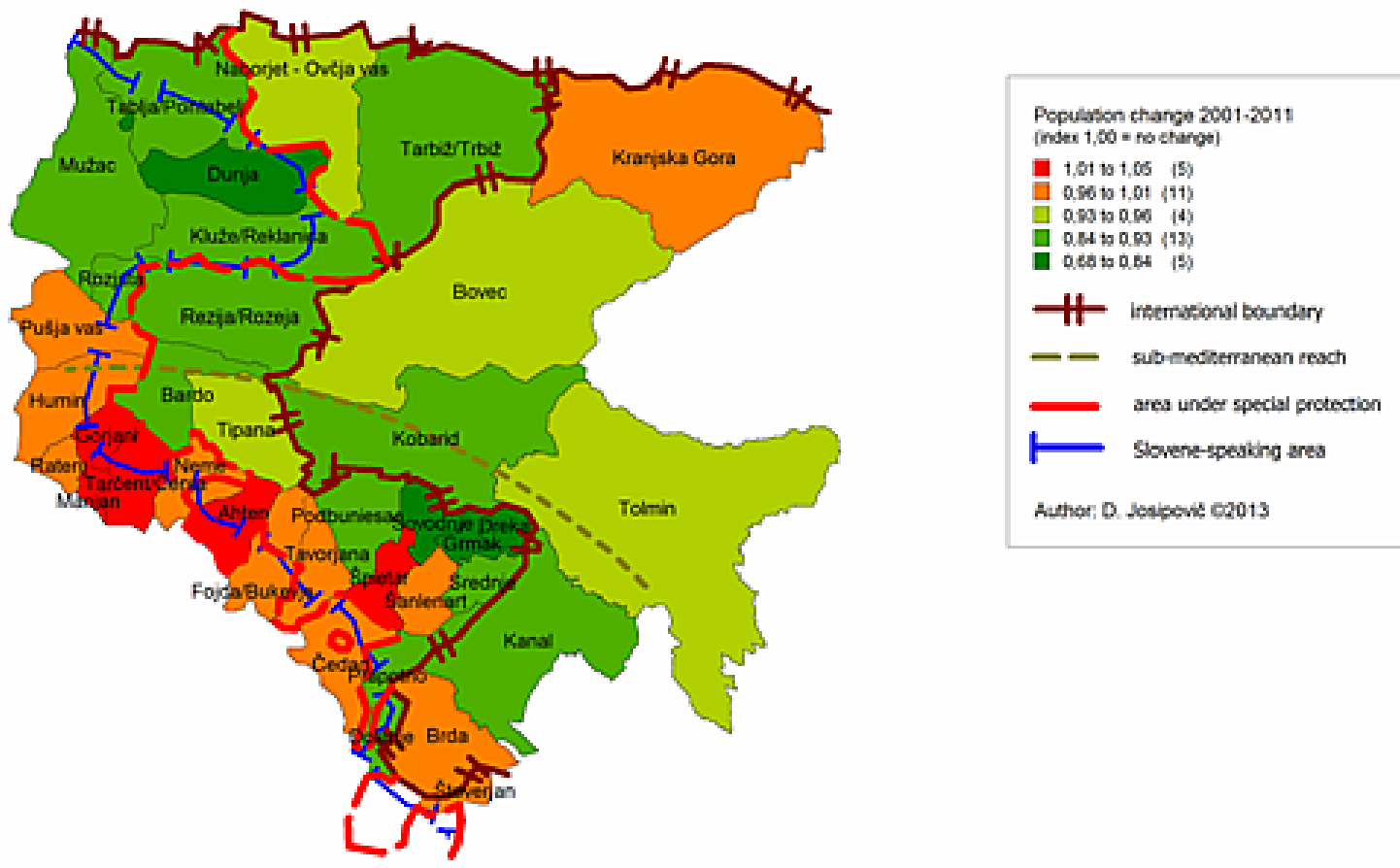

Map 3. Population change (2001-2011) at municipal level, Alpine and pre-Alpine borderland between Italy and Slovenia (sources: Italian Statistical Office, 2011; Statistical Office of Slovenia, 2011; additional calculations by the author). 
Nonetheless, in the beginning of 2001 , the Act $n^{\circ} 38$ on protection of Slovene-speaking minority in Friuli Venezia Giulia was approved. But lacking the concrete area of protection it took several years before the Presidential Decree in 2007 officially recognized 32 municipalities, which were obliged to follow and implement the legal provisions of Act $n^{\circ} 38$. As regards the traditional Slovene-speaking area, the Decree was rather inclusive, given that only four municipalities (Pontebba/Tablja, Montenars/Gorjani, Tarcento/Čenta, and Dolegna del Collio/Dolenje) of traditional presence of Slovene speakers were not at least partially encompassed (see Map 2, Table 2).

\begin{tabular}{|c|c|c|c|c|c|c|c|c|c|c|}
\hline Municipality & Subregion & Area $\left(\mathrm{km}^{2}\right)$ & $\begin{array}{l}\text { Population } \\
2001\end{array}$ & \begin{tabular}{|l|} 
Population \\
2011
\end{tabular} & \begin{tabular}{|l|} 
Indices \\
$2011 / 2001$
\end{tabular} & $\begin{array}{l}\text { Slovene } \\
\text { speakers } \\
\text { (2011 } \\
\text { estimation) }\end{array}$ & $\begin{array}{l}\text { Share of } \\
\text { Slovene } \\
\text { speakers }\end{array}$ & $\begin{array}{l}\text { Population } \\
\text { under the } \\
\text { legal } \\
\text { protection } \\
\text { ** }\end{array}$ & \begin{tabular}{|l|} 
Share of \\
municipal \\
population \\
under \\
protection**
\end{tabular} & $\begin{array}{l}\text { Municipal } \\
\text { area }\left(\mathrm{km}^{2}\right) \\
\text { under } \\
\text { protection** }\end{array}$ \\
\hline Attimis/Ahten & MIDSV & 33,61 & 1.833 & 1.865 & 1,02 & 877 & $47 \%$ & 1.865 & $100 \%$ & 33,61 \\
\hline Cividale del Friuli/Čedad & LOWSV & 50,94 & 11.373 & 11.338 & 1,00 & 3.515 & $31 \%$ & 1.134 & $10 \%$ & not defined \\
\hline Drenchia/Dreka & LOWSV & 12,78 & 197 & 134 & 0,68 & 134 & $100 \%$ & 134 & $100 \%$ & 12,78 \\
\hline Faedis/Fojda & MIDSV & 46,67 & 3.070 & 2.986 & 0,97 & 1.135 & $38 \%$ & 193 & $6,47 \%$ & 25,00 \\
\hline Grimacco/Garmak & LOWSV & 15,16 & 488 & 374 & 0,77 & 370 & $99 \%$ & 374 & $100 \%$ & 15,16 \\
\hline Lusevera/Bardo & UPSV & 53,67 & 788 & 706 & 0,90 & 699 & $99 \%$ & 706 & $100 \%$ & 53,67 \\
\hline \begin{tabular}{|l|} 
Malborghetto Valbruna/ \\
Naborjet - Ovčja vas
\end{tabular} & VALKAN & 124,97 & 1.036 & 972 & 0,94 & 535 & $55 \%$ & 972 & $100 \%$ & 124,97 \\
\hline Montenars/Gorjani & MIDSV & 20,15 & 536 & 558 & 1,04 & 201 & $36 \%$ & & & \\
\hline \begin{tabular}{|l|} 
Nimis/Neme \\
\end{tabular} & MIDSV & 33,18 & 2.825 & 2.785 & 0,99 & 641 & $23 \%$ & 238 & $8,53 \%$ & 10,00 \\
\hline Pontebba/Tablja & VALKAN & 100,97 & 1.768 & 1.506 & 0,85 & 120 & $8 \%$ & & & \\
\hline Prepotto/Prapotno & LOWSV & 32,59 & 899 & 811 & 0,90 & 365 & $45 \%$ & 811 & $100 \%$ & 32,59 \\
\hline Pulfero/Podbonesec & LOWSV & 49,12 & 1.202 & 1.035 & 0,86 & 1.014 & $98 \%$ & 1.035 & $100 \%$ & 49,12 \\
\hline Resia/Rezija & UPSV & 118,64 & 1.285 & 1.083 & 0,84 & 1.072 & $99 \%$ & 1.083 & $100 \%$ & 118,64 \\
\hline \begin{tabular}{|l|} 
San Leonardo/ \\
Šent Lenart
\end{tabular} & LOWSV & 26,68 & 1.169 & 1.164 & 1,00 & 1.152 & $99 \%$ & 1.164 & $100 \%$ & 26,68 \\
\hline $\begin{array}{l}\text { San Pietro al Natisone/ } \\
\text { Špeter Slovenov }\end{array}$ & LOWSV & 24,35 & 2.155 & 2.224 & 1,03 & 2.113 & $95 \%$ & 2.224 & $100 \%$ & 24,35 \\
\hline Savogna/Sovodnje & LOWSV & 22,48 & 659 & 483 & 0,73 & 483 & $100 \%$ & 483 & $100 \%$ & 22,48 \\
\hline Stregna/Srednje & LOWSV & 20,29 & 456 & 399 & 0,88 & 399 & $100 \%$ & 399 & $100 \%$ & 20,29 \\
\hline Taipana/Tipana & UPSV & 65,87 & 715 & 680 & 0,95 & 680 & $100 \%$ & 680 & $100 \%$ & 65,87 \\
\hline Tarcento/Čenta & MIDSV & 35,38 & 8.716 & 9.104 & 1,04 & 1.366 & $15 \%$ & & & \\
\hline Tarvisio/Trbiž & VALKAN & 209,03 & 5.071 & 4.597 & 0,91 & 827 & $18 \%$ & 4.597 & $100 \%$ & 209,03 \\
\hline Torreano/Tavorjana & MIDSV & 33,67 & 2.266 & 2.214 & 0,98 & 775 & $35 \%$ & 2.214 & $100 \%$ & 33,67 \\
\hline $\begin{array}{l}\text { Valcanale/Kanalska } \\
\text { dolina (VALKAN) }\end{array}$ & & 434,97 & 7.875 & 7.075 & 0,90 & 1.483 & $21 \%$ & 5.569 & $79 \%$ & 334,00 \\
\hline \begin{tabular}{|l} 
Upper Slavia \\
Veneta/Gornja \\
Benečija (UPSV) \\
\end{tabular} & & 238,18 & 2.788 & 2.469 & 0,89 & 2.451 & $99 \%$ & 2.469 & $100 \%$ & 66,26 \\
\hline $\begin{array}{l}\text { Middle Slavia } \\
\text { Veneta/ Srednja } \\
\text { Benečija (MIDSV) } \\
\end{array}$ & & 202,66 & 19.246 & 19.512 & 1,01 & 4.994 & $26 \%$ & 4.510 & $23 \%$ & 59,12 \\
\hline \begin{tabular}{|l} 
Lower Slavia \\
Veneta/ Dolnja \\
Benečija (LOWSV) \\
\end{tabular} & & 254,38 & 18.598 & 17.962 & 0,97 & 9.545 & $53 \%$ & 7.758 & $43 \%$ & 452,65 \\
\hline \begin{tabular}{|l|} 
TOTAL \\
\end{tabular} & & 1130,19 & 48.507 & 47.018 & 0,97 & 18.473 & $39 \%$ & 20.306 & $43 \%$ & 912,02 \\
\hline $\begin{array}{l}\text { Only municipalities } \\
\text { under the Act Nr. } 38\end{array}$ & & 1006,87 & 40.312 & 38.635 & 0,96 & & & 20.306 & $53 \%$ & \\
\hline
\end{tabular}

Tab 2. New quantitative estimates on the Slovene-speaking population in the area of traditional presence, Province of Udine, Italian part of the border region (sources: Istat, 1983; 2001; 2011; Stranj, 1999, Act nr. 38, 2001; Presidential Decree, 2007; new estimations by Josipovič, 2013).

As for migration, there was a sharp increase in international migration ever since the fall of Berlin Wall. After (and somewhat simultaneously with both "natural" demographic transitions) the so-called "mechanical" (i.e. the third) transition commenced. International migration has led to larger shares of foreign population and to major changes in previously dichotomous ethnodemographic structure of the region. The period 2003-2009 marked by economic conjuncture brought so far the highest increase in shares of foreign citizens and led to its doubling despite the onset of the economic crisis (Table 3 ). 


\begin{tabular}{|r|r|r|r|r|r|}
\hline Foreign population & $\begin{array}{l}\text { Udine } \\
\text { Province }\end{array}$ & $\begin{array}{l}\text { Gorizia } \\
\text { Province }\end{array}$ & $\begin{array}{l}\text { Trieste } \\
\text { Province }\end{array}$ & $\begin{array}{l}\text { Pordenone } \\
\text { Province }\end{array}$ & $\begin{array}{l}\text { Region of Friuli- } \\
\text { Venezia Giulia }\end{array}$ \\
\hline $\mathbf{2 0 0 3}$ & 15.564 & 4.283 & 10.655 & 12.996 & $\mathbf{4 3 . 4 9 8}$ \\
\hline $\mathbf{2 0 0 3}$ share in total population (\%) & 3,0 & 3,1 & 4,4 & 4,5 & $\mathbf{3 , 7}$ \\
\hline $\mathbf{2 0 0 4}$ & 18.654 & 5.165 & 11.432 & 16.638 & $\mathbf{5 1 . 8 8 9}$ \\
\hline $\mathbf{2 0 0 4}$ share in total population (\%) & 3,6 & 3,7 & 4,8 & 5,7 & $\mathbf{4 , 3}$ \\
\hline $\mathbf{2 0 0 5}$ & 21.689 & 5.953 & 11.541 & 19.732 & $\mathbf{5 8 . 9 1 5}$ \\
\hline $\mathbf{2 0 0 5}$ share in total population (\%) & 4,1 & 4,2 & 4,8 & 6,6 & $\mathbf{4 , 9}$ \\
\hline $\mathbf{2 0 0 6}$ & 24.166 & 6.600 & 12.406 & 22.013 & $\mathbf{6 5 . 1 8 5}$ \\
\hline $\mathbf{2 0 0 6}$ share in total population (\%) & 4,6 & 4,7 & 5,2 & 7,3 & $\mathbf{5 , 4}$ \\
\hline $\mathbf{2 0 0 7}$ & 26.680 & 7.451 & 13.436 & 24.895 & $\mathbf{7 2 . 4 6 2}$ \\
\hline $\mathbf{2 0 0 7}$ share in total population (\%) & 5,0 & 5,3 & 5,7 & 8,2 & $\mathbf{6 , 0}$ \\
\hline $\mathbf{2 0 0 8}$ & 31.313 & 8.360 & 14.852 & 28.781 & $\mathbf{8 3 . 3 0 6}$ \\
\hline $\mathbf{2 0 0 8}$ share in total population (\%) & 5,8 & 5,9 & 6,3 & 9,4 & $\mathbf{6 , 8}$ \\
\hline $\mathbf{2 0 0 9}$ & 35.588 & 9.688 & 16.528 & 33.172 & $\mathbf{9 4 . 9 7 6}$ \\
\hline $\mathbf{2 0 0 9}$ share in total population (\%) & 6,6 & 6,8 & 7,0 & 10,6 & $\mathbf{7 , 7}$ \\
\hline
\end{tabular}

Tab 3. Foreign population in Friuli Venezia Giulia, region, provinces, 2003-2009 (source: Italian Statistical Office, 2012).

The most significant rise was registered in Pordenone province, where it eventually tripled. The same province is the only one with foreign population exceeding $10 \%$ margin (see Table 3 ). All four Friulian provinces, including Udine, experienced a migratory burst in the last decade. The structure of foreign population in Friuli Venezia Giulia became complicated as well. According to the citizenship, the major share went to the former Yugoslavia's successor nationalities with $26 \%$. Additional $30 \%$ accounted for both, the Romanian and Albanian nationals. The remainder of $44 \%$ is heavily dispersed: $7 \%$ for former Eastern Bloc countries of Poland, Ukraine, and Moldova; $5 \%$ for Maghreb countries of Morocco and Tunisia; and another $5 \%$ for Ghana; India and PR China nationals peaked at 3\% each, etc. (see Figure 1).
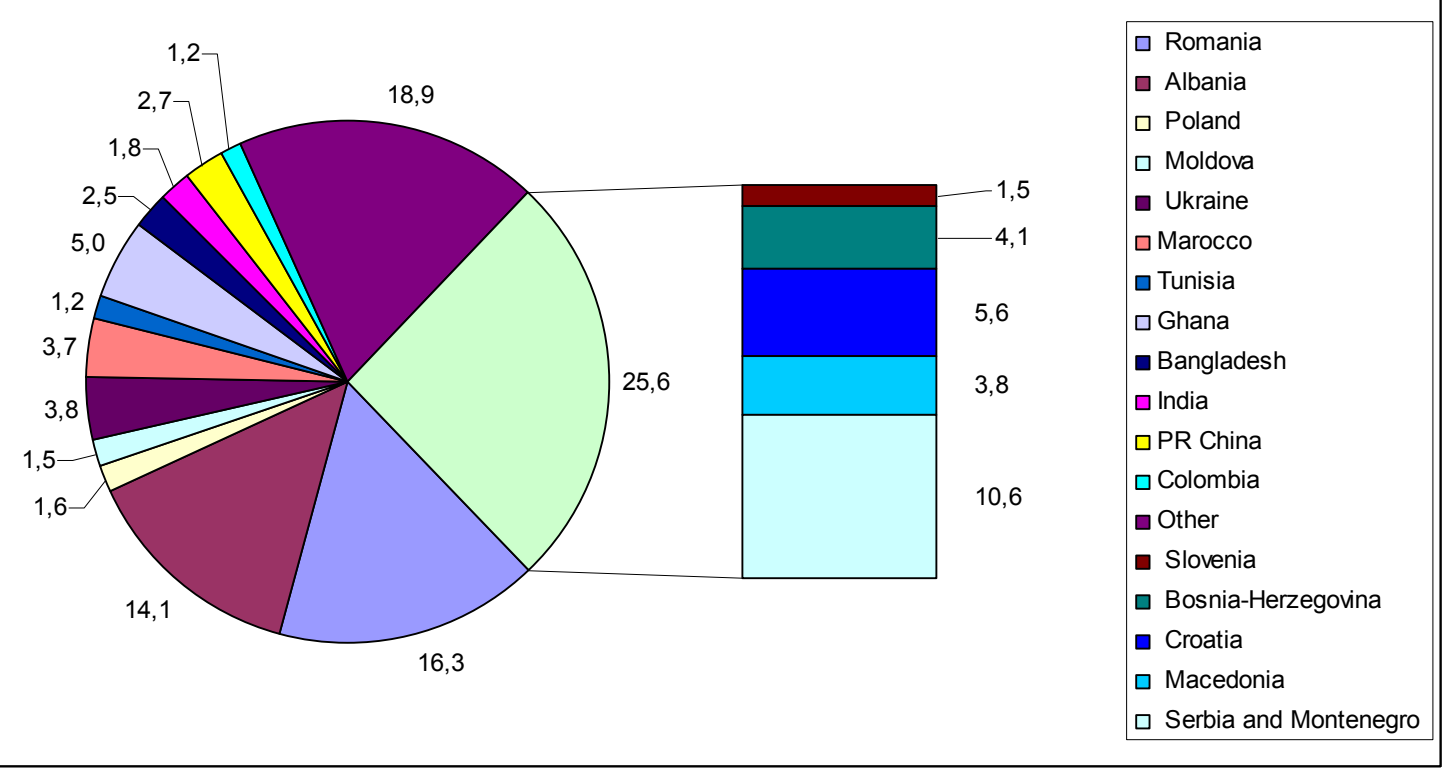

Fig 1. Citizenships of the foreign population in Friuli Venezia Giulia (source: Italian Statistical Office, 2012).

As regards the municipal level, the citizenships data is not at our disposal. Nevertheless, we may infer to migration trends according to the overall migration statistics. The municipal data for 2011 show that the principal recent migration flows were directed predominantly towards the industrial and employment centres outside the studied region (Table 4). Compared to 6.6\% (Udine) and $6.8 \%$ (Gorizia) on provincial level, the local share in the studied area is substantially 
lower (5.3\% and $1.7 \%$ respectively). Some municipalities, however, exercise higher immigrant shares due to other, mostly geo-political reasons. Such case is Taipana/Tipana municipality, where a small community of Bosnian refugees remained to stay permanently (Allessio, 2011).

\begin{tabular}{|c|c|c|c|}
\hline Comune & \begin{tabular}{|l|} 
Population \\
2011
\end{tabular} & \begin{tabular}{|l} 
Foreign \\
population \\
2011 \\
\end{tabular} & $\begin{array}{l}\text { Percentage of } \\
\text { foreign } \\
\text { citizens }\end{array}$ \\
\hline Artegna & 2.879 & 108 & $4 \%$ \\
\hline Attimis & 1.865 & 83 & $4 \%$ \\
\hline Chiusaforte & 704 & 19 & $3 \%$ \\
\hline Cividale del Friuli & 11.338 & 825 & $7 \%$ \\
\hline Dogna & 192 & 1 & $1 \%$ \\
\hline Drenchia & 134 & 6 & $4 \%$ \\
\hline Faedis & 2.986 & 143 & $5 \%$ \\
\hline Gemona del Friuli & 11.153 & 521 & $5 \%$ \\
\hline Grimacco & 374 & 5 & $1 \%$ \\
\hline Lusevera & 706 & 39 & $6 \%$ \\
\hline Magnano in Riviera & 2.367 & 82 & $3 \%$ \\
\hline Malborghetto Valbruna & 972 & 30 & $3 \%$ \\
\hline Moggio Udinese & 1.816 & 78 & $4 \%$ \\
\hline Montenars & 558 & 19 & $3 \%$ \\
\hline Nimis & 2.785 & 138 & $5 \%$ \\
\hline Pontebba & 1.506 & 72 & $5 \%$ \\
\hline Prepotto & 811 & 15 & $2 \%$ \\
\hline Pulfero & 1.035 & 115 & $11 \%$ \\
\hline Resia & 1.083 & 6 & $1 \%$ \\
\hline Resiutta & 315 & 13 & $4 \%$ \\
\hline San Leonardo & 1.164 & 105 & $9 \%$ \\
\hline San Pietro al Natisone & 2.224 & 117 & $5 \%$ \\
\hline Savogna & 483 & 33 & $7 \%$ \\
\hline Stregna & 399 & 20 & $5 \%$ \\
\hline Taipana & 680 & 95 & $14 \%$ \\
\hline Tarcento & 9.104 & 483 & $5 \%$ \\
\hline Tarvisio & 4.597 & 272 & $6 \%$ \\
\hline Torreano & 2.214 & 141 & $6 \%$ \\
\hline Venzone & 2.230 & 41 & $2 \%$ \\
\hline Dolegna del Collio & 392 & 12 & $3 \%$ \\
\hline San Floriano del Collio & 799 & 8 & $1 \%$ \\
\hline Udine Province & 68.674 & 3625 & $5,3 \%$ \\
\hline Gorizia Province & 1.191 & 20 & $1,7 \%$ \\
\hline
\end{tabular}

Tab 4. Foreign citizens in the municipalities of Italian part of the borderland (source: ISTAT, 2011).

\subsection{Slovenian part}

In the absence of firmer territorial subdivisions, and with respect to non-existent administrative division at NUTS3 level, Slovenia is undergoing processes of strong centralization (Josipovič 2009). As one of the six ex-Yugoslav republics, it was the only one to share as many as three international boundaries and as little as one internal boundary with other federal entities. Its geographical position between Italy, Austria, Hungary, and Croatia, and with an access to Adriatic Sea, ranks Slovenia among the most physically and geopolitically diverse European 
countries compared to its size. But even in a relatively small country one may find its peripheral parts. One of such is the Slovenian northwest, which represents the eastern part of the studied borderland.

As stated above, the last Slovenian census of 2011 was the first ever to be carried out by the transversal snapshot of population registers and various databases at the critical moment of the $1^{\text {st }}$ of January. Slovenia is thus one of the six countries in Europe implementing the register censuses (Dolenc, 2009). Despite the constraints in population analyses and limited application of various indicators due to narrowed variable sets at the so-called register census, Slovenia still operates with some relatively recent data on ethnic structure at the level of NUTS3 regions. Unfortunately the official data is not available at the level of municipalities, so we had to apply the alternative methods to assess the number of Italians ${ }^{6}$ (or Friulians) in the Slovenian part of the borderland.

The new migration trends in Slovenia show slightly different picture. Though continuously increasing, the share of Slovenian residents with foreign citizenships is still well beneath $10 \%$. The Slovenian part of the border region undergoes the same processes, with the number of Italians expectedly low (31 persons). When speaking of those stating Italian as a mothertongue, the numbers are twice as high (73 persons; Table 5). Yet, these are the data from the last census in 2002 which included questions on mother-tongue and ethnicity. The recent data on citizenship and place of birth show changes in the local cross-border dynamics. The number of Italian citizens in Slovenia rose to around 1.000 (981 in 2012). According to the place of birth, the number of Italy-born residents in Slovenia exceeds 3,000 (Table 6). At the regional level, the Goriška region shows negative balance of Slovenian citizens with Italy, though the overall balance is positive (around 100 in 2011; Table 6).

\begin{tabular}{|l|r|r|}
\hline & 2002 & 2002 \\
\hline & & \\
Municipality & & \\
& Italians & \multicolumn{2}{|l|}{ Italian mother- } \\
& 3 & 7 \\
\hline Bovec & 5 & 11 \\
\hline Brda & 6 & 15 \\
\hline Kanal & 4 & 12 \\
\hline Kobarid & 3 & 4 \\
\hline Kranjska Gora & 10 & 24 \\
\hline Tolmin & 31 & 73 \\
\hline TOTAL & 100 & 210 \\
\hline Goriška region & 2258 & 3762 \\
\hline SLOVENIA & & \\
\hline
\end{tabular}

Tab 5. Population of Italian ethnic affiliation and mother tongue in Slovenian part of the border region, municipalities (source: SORS, Census 2002).

\begin{tabular}{|c|c|c|c|c|c|c|c|c|c|}
\hline & 2011 & 2012 & 2011 & 2011 & 2011 & 2011 & 2011 & 2011 & 2011 \\
\hline & $\begin{array}{l}\text { Italian } \\
\text { citizenshi } \\
\text { p }\end{array}$ & $\begin{array}{l}\text { Italian } \\
\text { citizenshi } \\
\text { p }\end{array}$ & $\begin{array}{l}\text { Italy as a } \\
\text { country of } \\
\text { the first } \\
\text { residence }\end{array}$ & $\begin{array}{l}\text { citizens of } \\
\text { Slovenia }\end{array}$ & $\begin{array}{l}\text { Foreign } \\
\text { citizens }\end{array}$ & $\begin{array}{l}\text { Emigrants } \\
\text { to Italy - } \\
\text { foreigners }\end{array}$ & $\begin{array}{l}\text { Emigrants } \\
\text { to Italy - } \\
\text { Slovenians }\end{array}$ & $\begin{array}{l}\text { Immigrant } \\
\text { s from } \\
\text { Italy - } \\
\text { Slovenians }\end{array}$ & $\begin{array}{l}\text { Immigrant } \\
\text { s from } \\
\text { Italy - } \\
\text { foreigners }\end{array}$ \\
\hline \multicolumn{2}{|c|}{ GORIŠKA region } & & & & & 184 & 281 & 240 & 322 \\
\hline Slovenia & 870 & 981 & 3134 & 2363 & 771 & & & & \\
\hline
\end{tabular}

Tab 6. Immigration to Slovenia and to Goriška statistical region (2011-2012) from Italy (source: SORS, migration statistics).

\footnotetext{
${ }^{6}$ The number of Friulians is not possible to establish since the statistical categories do not provide a pertinent statistical category.
} 
It is hard to compare migration statistics across the border due to different methodologies in recent years. Nonetheless, for the Slovenian part it is clear that the influx of foreign citizens improves the overall population structure. While Brda municipality show positive trends in both internal and international migration, all other municipalities (with Kanal municipality at the opposite extremity) experienced moderate net immigration and strong net out-migration (Table 7).

\begin{tabular}{|l|r|r|r|r|}
\hline & \multicolumn{4}{|c|}{$\mathbf{2 0 0 0} \mathbf{- 2 0 1 1}$} \\
\hline Bovec & $\begin{array}{c}\text { Net migration } \\
\text { between } \\
\text { municipalities }\end{array}$ & $\begin{array}{c}\text { Overall } \\
\text { net } \\
\text { migration }\end{array}$ & $\begin{array}{c}\text { International } \\
\text { migration per } \\
1000 \text { inhabitants }\end{array}$ & $\begin{array}{c}\text { Migration between } \\
\text { municipalities per } \\
1000 \text { inhabitants }\end{array}$ \\
\hline Brda & -30 & 87 & 36,1 & $-10,2$ \\
\hline Kanal & 77 & 144 & 11,5 & 13,5 \\
\hline Kobarid & -483 & -368 & 19,3 & $-81,7$ \\
\hline Kranjska Gora & -184 & -74 & 25 & -4 \\
\hline Tolmin & -25 & 36 & 11,4 & $-46,4$ \\
\hline TOTAL & -553 & -132 & 35,3 & \\
\hline
\end{tabular}

Tab 7. Migration trends in Slovenian part of the border region in the period 2000-2011, municipalities (source: SORS, migration statistics).

\subsection{Reproduction of population}

In the era of generally high life expectancy, we might consider fertility as a key component of natural population change. The total population may be affected by locally-specific death or migration rates but fertility remains vital to any part of the world's population.

When considering the recent demographic development in the border region one cannot avoid the question on the population reproduction. To address this question we applied a special demographic-indicator, which helps us understand the developments at mezzo- and micro- level in more depth. The need to apply such an indicator stems out of a lack of suitable statistical data. While we may expect, as we have already shown, that the data in most cases aggregate until the level of the provinces, we may not be able to explain locality-specific phenomena as, for example, fertility behaviour. Hence we employed the so-called "approximative reproductive potential" (ARP) ${ }^{7}$, which is designed to apprehend the fertility trends, when more detailed data are missing. The main feature of this indicator lies in its ability to portray the actual fertility by combining the number of births directly to the number of women able to give births. This feature makes it directly comparable to renowned total fertility rate (TFR) indicator.

As to the questions of fertility in our case, the map 4 shows substantial variation of the local rates of ARP. The highest rates were recorded in the most mountainous areas like Resia, Resiutta, and Chiusaforte. Despite relatively lower values (up to 1,6 children per woman), these values stand out of the region's average, and are well above the national average $(1,4)$, too. The discrepancy between the total population change and the fertility rates on maps 3 and 4 is only partially unexpected. According to the research results from the three Slovenian cases (see Josipovič 2003; 2004), we might expect the higher fertility rates in areas with "higher relief energy". In this way the relatively higher fertility rates in mountainous municipalities fit perfectly into the aforementioned paradigm. Yet, some (sub-) Alpine municipalities failed to fit within such paradigm. Namely, the areas with unfavourable age structure and low number of inhabitants (like Drenchia/Dreka and Dogna/Dunja municipalities) are at the brink of complete inability of recovering. The prospects there head towards complete depopulation since the fertile contingent of the local population is dramatically shrunk.

\footnotetext{
${ }^{7}$ The indicator is thoroughly explained and applied in Josipovič (2006).
} 

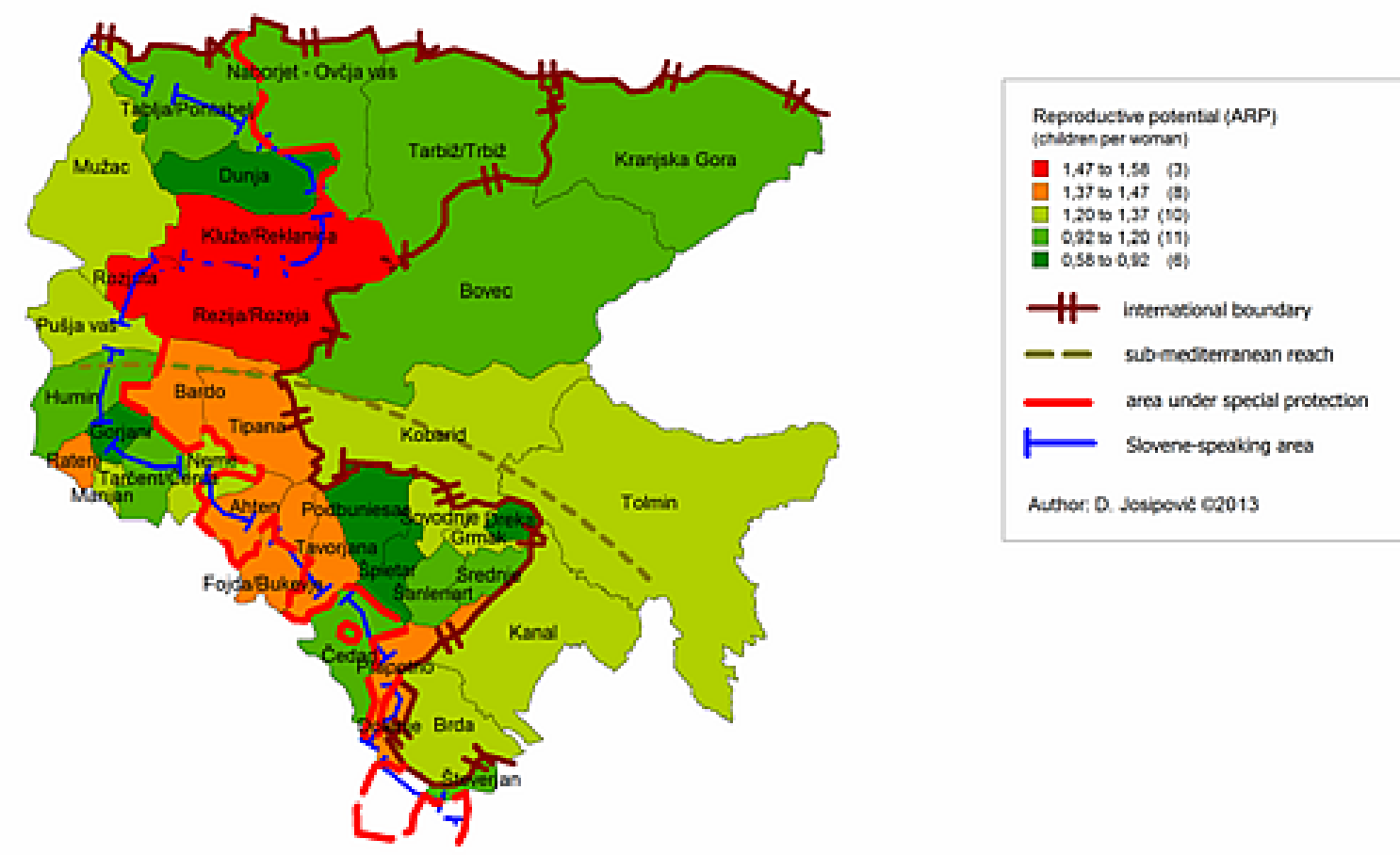

Map 4. Reproductive potential (APR) at municipal level in 2011, Alpine and pre-Alpine borderland (sources: Italian Statistical Office, 2011; Statistical Office of Slovenia, 2011; calculations by the author).

Nevertheless, when comparing the indices of population change and reproduction rates with the accessible migration statistics we might witness rather similar development on both sides of the border with some peculiarities, one of them being the net immigration in combination with extremely low fertility. Such cases are Bovec and Kranjska Gora municipalities in Slovenia, and S. Pietro al Natisone / Špietar and Pulfero / Pudboniesac in Italy (Tables 4 and 5, Map 3 and 4).

\section{Conclusion - a transformation of the countryside settlement pattern}

The borderland between Slovenia and Italy is suffering a loss of population for decades. Contrary to the recent developments in autonomous region Friuli Venezia Giulia, the population in Slavia Veneta (Italian part of the borderland) is continuously diminishing. In the first place, there are clear signs that the population in the smallest municipalities will lose all the potentials to run their municipality. Such cases are Dogna and Drenchia with less than 200 inhabitants. While Dogna is situated in an isolated mountainous valley, Drenchia lies in an easternmost hilly part of the Natisone Valleys (Nadiža) and directly borders Slovenia. This border triangle is supplemented by two other municipalities with high rate of depopulation (Savogna and Grimacco). These four municipalities have lost between 26 and 32 percent of its population in the last decade only. Except Dogna, these rural municipalities are a "stronghold" of Slovenespeaking minority in Udine Province. On the other end of the tale we find municipalities with a slight increase in population: $1.7 \%-4.5 \%$ in the last decade (2001-2011). All are situated in the southernmost part of the Prealps, and except Montenars all of them possess central settlement with urban or semi-urban character. It is significant, though somewhat surprising, that the most important Slovene-speaking centre of this area, San Pietro al Natisone (Špietar Slovenov), exercise one of the highest regional indices of population growth $(+3 \%)$. On the other hand all of the surrounding municipalities are losing population. One reason lies in a fact that the local centres including Cividale del Friuli and Gemona are too weak to attract additional population, so the latter moves to cities in close proximity (Udine, Gorizia, and somewhat Trieste). The new trend of increasing in Špietar's population may result also from the local concentration of Slovene-speaking population, rather than distribution around the Region of Friuli Venezia Giulia.

Recent statistical and demographic data show that the region of Friuli Venezia Giulia (FVG) is undergoing a significant shift of population. On one hand, there are signs of social emancipation 
of Slovenes and Friulians respectively, while on the other, the recent demographic development shows urban and suburban concentration of foreign citizens which reconstitutes the former rather dual traditional ethnic relationships.

The Slovene-speaking population on both sides of the boundary remains the prominent characteristic of this hilly and mountainous borderland. In spite of geographical contiguity to Slovenia, the local population had rather sparse cross-border connections due to specific configuration of the terrain, high relative altitudes, and more or less low number of bordercrossings. In bipolar geopolitical circumstances and the Iron Curtain, the cross-border cooperation was highly disturbed or even impossible. The boundaries created half a century ago gradually moved from a point of radical superimposition to a point of production and reproduction of the sense of a region (cf. Paasi, 1986). The traumatic Cold war era brought some ease with bilateral agreements between Italy and Yugoslavia on the border traffic and made life bearable for the people 'on the border'. After the collapse of the Eastern political bloc and the break-up of the Yugoslavia, both parts of the border region started to re-establish and redevelop former ties which culminated in recent euro-region initiatives (e.g. Gasparini, 2002). With the EU enlargement and with the extension of the Schengen border regime, these initiatives became, in a way, obsolete, though not unimportant.

Overall population change in the last surveyed decade (2001-2011) shows stagnation rather than strong depopulation. The settlement pattern still persists, though the number of uninhabited houses increases. The overall demographic picture seems to be more 'favourable' in Italian part, while the exclusion of towns on the southern rim (from Gemona to Cividale) renders a completely different picture. The Valcanale suffers demographic loss at around $10 \%$, while the whole Alpine part (8 municipalities) lost as much as $12 \%$. The exception is the predominantly Slovene-speaking municipality of Malborghetto Valbruna with 'only' $6 \%$ decrease, which is en par with the Slovenian part of the region.

This might signal that the traditional Slovene-speaking areas in recent periods developed a higher affinity of staying, instead of emigrating, compared to the neighbouring (mostly Friulianspeaking) municipalities. Moreover, it seems that they are attractive for immigration too (attractive landscape, low population density, lots of space and woods, quietness, unspoiled environment and alike), since low fertility rates (under 1.6 children per woman) cannot contribute to the demographic increase. Nevertheless the reproduction rate as an indicator of fertility behaviour is generally higher in Alpine municipalities, especially in remote valleys (Resiutta, Resia, Chiusaforte), and generally outside the core of Slovene-speaking area in Italy. Here as well, the fertility rates depend upon the relief, which is in line with the findings in Slovenia (Josipovič, 2003, 2004), as long as a micro-region retains sufficient population (generally above 500 inhabitants; with 300 as a minimum). Accordingly, it should be stressed that the rural settlements and municipalities are under heavier pressure and more demographically endangered across both sides of the border region, precisely due to low number of population, and not due to ageing as might be expected and propagated.

Future prospects of the border region are not as dark as many might depict. The settlement pattern and the overall demographic structure must be seen as an advantage. The people who stay, who do not emigrate, slowly orient back to the sustainable farming, which should remain a primary goal in preventing depopulation. A landscape and unspoiled nature could be used in a way to attract individuals or families depending on the quietness as an inspiration of creating. The transformation of Toppolò/Topolovo into a village of art is an interesting way in so doing. The official bilinguism and trilinguism (Friulian-Slovene-Italian) is an excellent opportunity in attracting people from both sides of the border and from the third countries. The governments should protect the whole region as a valuable cultural landscape of paramount importance regardless of who actually inhabits the countryside as long as the people remain there. And finally, these actions should operate to preserve, and not to prevent. 
[1] Alessio, A. (2011). Vivere da stranieri a Taipana (Alta Valle del Torre-Ud). Paper presented at the conference in Rovigo, 19.03.2011.

[2] Bank of Statistical Data. Statistical Office of the Republic of Slovenia (SORS), www.stat.si.

[3] Bufon, M. (1992). Prostorska opredeljenost in narodna pripadnost: obmejna in etnično mešana območja v evropskih razvojnih silnicah: primer Slovencev v Furlaniji-Julijski krajini. Trieste: Založništvo tržaškega tiska.

[4] Coleman, D. (2006). Immigration and ethnic change in low fertility countries. A third demographic transition. Population and Development Review 32(3), 401-446. Doi: 10.1111/j.1728-4457.2006.00131.x.

[5] Dolenc, D. 2009. Registrski popis prebivalstva v letu 2011 - nov izziv Slovenske državne statistike. Statistidal days, Radenci, Slovenia. Available at: http://www.stat.si/StatDnevi2009/Docs/Dolenc-

Registrski\%20popis\%20prebivalstva_prispevek.pdf (accessed: 26.04.2013).

[6] Feigel, D. \& Nanut, V. (1950). Beneška Slovenija. Gorizia/Gorica: G. Carducci.

[7] Gasparini, A., ed. (2002). Progetto di sviluppo e conoscenza reciproca Italo-Slovena. San Pietro al Natisone: Comunita Montana Valli del Natisone.

[8] Harvey, D. (1989). The urban experience. Baltimore: Johns Hopkins University Press.

[9] Massey, D. B. (1993). Power-geometry and a progressive sense of place. In Bird J. et al., eds., Mapping the Futures: Local Cultures, Global Change (pp. 59-69). London: Routledge.

[10] Italian Statistical Office (ISTAT), www.istat.it.

[11] Jenks, G. F. \& Caspall, F. C. (1971). Error on Choroplethic Maps: Definition, Measurement, Reduction. Annals of American Geographers 61(2), 217-244. Doi: 10.1111/j.14678306.1971.tb00779.x.

[12] Jones, S. B. (1959). Boundary Concepts in the setting of place and time. Annals of the Association of American Geographers, 49(3), 241-255. Doi: 10.1111/j.14678306.1959.tb01611.x.

[13] Josipovič, D. (2003). Geographical Factors of Fertility. Acta Geographica Slovenica. Ljubljana: Adam Melik Institute Geographical Instiute of ZRC/SAZU.

[14] Josipovič, D. (2004). Factors of Fertility Behaviour in Slovenia. Ljubljana: Založba ZRC.

[15] Josipovič, D. (2006). The Impacts of Immigration to Slovenia After WWII. Ljubljana: Založba ZRC.

[16] Josipovič, D. (2007). Spremembe etnične strukture prebivalstva v Sloveniji po letu 1991. Treatises and Documents, 53-54, 98-115.

[17] Josipovič, D. (2009). Razprava o odnosu center - periferija: peripanonski slovensko-hrvaški stik v sistemu širitve EU. In Gosar A., ed., Development opportunities of Slovenian border regions (pp. 197-211). Koper: Annales.

[18] Kos, M. (1933). Zgodovina Slovencev. Ljubljana: Jugoslovanska knjigarna.

[19] Melik, A. (1950). Planine v Julijskih Alpah. Ljubljana: Institute of Geography. SASA.

[20] Mlekuž, J. (2002). Proučevanje učinkov migracij na vrednotenje prostora med izseljenci iz Nadiške Beneške Slovenije Master's thesis. Ljubljana: University of Ljubljana.

[21] Mlekuž, J. (2004). Izbrani vidiki zaposlovanja beneških deklet v gospodinjstvih italijanskih mest: tiha grenko-sladka, nikoli povsem izrečena in slišana zgodba Dve Domoviny 19, 141164.

[22] Paasi, A. (1986). Institutionalization of Regions. Fennia. 16, 1-46. 
[23] Roglić, J. (1946). Le Recensement de 1910: ses méthodes et son application dans la Marche Julienne. Sušak: Institut adriatique.

[24] Rutar, S. (1899). Beneška Slovenija. Ljubljana: Matica Slovenska.

[25] Stranj, P. (1983). Demografsko gibanje v Furlaniji-Julijski krajini In Bolčič, ed., Jadranski koledar 1983 (pp. 131-135). Trieste: Založništvo tržaškega tiska.

[26] Stranj, P. (1999). Slovensko prebivalstvo Furlanije-Julijske krajine v družbeni in zgodovinski perspektivi. Trieste: SLORI. 